\title{
Farmer Water Management Strategies for Dry Season Water Shortages in Central Lombok, Indonesia
}

\author{
John Klock ${ }^{1}$, Taslim Sjah ${ }^{2}$ \\ ${ }^{1}$ Linn-Benton Community College, Albany, Oregon, USA; ${ }^{2}$ University of Mataram, Mataram, Indonesia. \\ Email: biology@hotmail.com, taslim_sjah@yahoo.com.au
}

Received January $30^{\text {th }}, 2011$; revised March 27 $7^{\text {th }}, 2011$; accepted April $7^{\text {th }}, 2011$.

\begin{abstract}
This paper examines how farmers in central Lombok have organized themselves to manage agricultural water collectively and to adapt to seasonally dry conditions. We interviewed eighteen village heads from October to December 2006. One of our questions we posed prior to field interviews was what might be the social and technical coping strategies that have allowed farmers to survive the lengthy dry seasons under the high population density of Lombok island. Some examples of organizational structure and practices in Central Lombok are presented. There were several common water management strategies that were revealed from these interviews including: methods of organization, flexible cropping systems, water allocation mechanisms, methods of compromise, alternative payments, and traditional water management practices. The statistical analysis comparing village characteristics and coping strategies suggests a relation between mosque number per village and farmers ability to cope. Farmers have shown their own unique coping strategies in times of water shortages and under decentralization occurring over the past decade. This decentralization involved turning over small scale irrigation systems (under 500 hectares), to the water user associations themselves in order to facilitate more efficient management and maintenance.
\end{abstract}

Keywords: Water User Associations, Subak, In-Kind Payments, Critical Dry Lands, Coping Strategies, Adaptation, Cropping Systems

\section{Introduction}

Water management is a major concern in Indonesia where state support of rice-based agriculture has been dominant for decades. Key to the success of rice production are water user associations (WUAs) who perform a critical role in negotiating with government bureaucracies and organizing agricultural water flows to farmers. Water shortages are chronic throughout many parts of Indonesia including Lombok, West Nusa Tenggara Province [1]. With greater frequency and intensity, the dry periods, prior to the first planting season, are becoming longer and less predictable most likely due to climate change and periodic El Nino events [2]. In 1966, 10,000 to 50,000 people died of famine on the island from crop failure brought about by drought. Famines are also recorded by the Dutch in the years 1894, 1927-1928, 1937-1938, 1939-1949, 1946-1947, 1956-1957, 19641966, 1968-1969, 1972-1973, and 1976-1977 [1].

Lombok is one of the most densely populated islands in Indonesia and central and Eastern Lombok is prone to drought. One question posed by the authors prior to field interviews was what might be some social and technical coping strategies that have allowed farmers to survive the lengthy dry seasons and drought periods and under high population densities? Some examples of organizational structure and practices in central Lombok are presented along with a general overview of water management in Lombok and Indonesia.

\section{Materials and Methods}

\subsection{Methodology}

The authors visited eighteen villages and interviewed eighteen kepala desa (village heads) in a sub-watershed at elevations ranging from sea level to 450 meters. Out of the 18 villages, 14 were analyzed statistically in this study for specific characteristics that might influence village adaptations as related to physical and socio-cultural institutions of the village. Climate variations and 
proximity to springs vary dramatically in central Lombok hence we chose a transect of villages for interviews, from sea level to 450 meters, to account for these differences. Analyzing villages by specific physical and institutional characteristics allowed for a comparison of water management strategies among villages with similar water sources.

The authors' interviews were semi-structured and took place over three months from October to December 2006. The authors asked fifteen to twenty questions pertaining to water use, management, conflict resolution, and survival mechanisms under water duress. The interviews were structured to authenticate specific answers in other villages. For example, village heads were asked questions about water management or infrastructure to verify information discussed in other villages.

Interview data from coping strategies was compared to specific village characteristics including: population, elevation, rainfall, village area, primary and secondary water sources for agriculture, mosque number, mosque number-land area ratio, and mosque number-population ratio. These village characteristics were gathered through the provincial statistical handbook [3] and via a GIS data set for Nusa Tenggara Barat [4].

Weighted scores were calculated for each sub-category by taking the number of affirmative responses for a specific coping strategy under a sub-category (ex. Village water institutions) and dividing these by the number of strategies in each sub-category for each village. ${ }^{1} \mathrm{~A}$ multiple linear regression model was used to describe the relationship between weighted scores and independent variables (village characteristics) at the $95 \%$ confidence level.

Villages were not randomly chosen and this study uses associations (not causations) of how coping strategies are related to village characteristics. Weighted scores were analyzed using scattered matrices that plotted independent and dependent variables (coping strategies). Elevation levels and precipitation numbers were given ordinal classifications (1, 2, and 3) for low, medium, and higher elevation respectively; as well as low precipitation, medium, and high precipitation areas respectively. There were two categories used here for water sources coded as binary variables (well $=0$, and spring $=1$ ). The backward elimination method used in this model with least significant variables removed first. Finally, R-squared was calculated to determine model fit and variability of the weighted score.

\footnotetext{
${ }^{1}$ (As an example, a particular village scored 18 affirmative responses divided by 4 coping strategies $=$ weighted score of 4.5 ) by village. This weighted average for each village was calculated across all sub-categories.
}

\subsection{Study Area}

Lombok has been a significant rice producing center in Southeast Asia. This importance cannot be overlooked in relationship to how farmers make the best use of their land today. Lombok contains a rich mixture of ethnicities, cultures, land policies, and colonial influences. Gelles notes that irrigation cultures cannot be removed for study from their "technical and economic properties, but should be analyzed as socially, culturally, and historically situated" [5].

Lombok Island is in the province of West Nusa Tenggara and lies at a latitude of $8^{\circ} 12^{\prime}$ and $8^{\circ} 55^{\prime}$ South and a longitude $115^{\circ} 46^{\prime}$ and $116^{\circ} 28^{\prime}$ East (Figures 1 and 2). Lombok has an area of $4,619 \mathrm{~km}^{2}$ and spans $60 \mathrm{~km}$ by 80 $\mathrm{km}$ at its widest point. Located just at the Wallace line, rainfall for Southern Lombok is noted at $948 \mathrm{~mm}$ and $1665 \mathrm{~mm}$ at 100 meters above sea level and 180 meters above sea level respectively [6]. East Lombok gets roughly $700 \mathrm{~mm}$ per year. The dry season is thus very pronounced and lasts from July to October.

The population of Lombok has increased from 1.48 million in 1971 to 2.1 million in 1990 to around 2.9 million people today [3]. With approximately 618 persons $/ \mathrm{km}^{2}$, Lombok has the highest population density in the province. By contrast, Bali has a population density of about 534 people per $\mathrm{km}^{2}$ residing on $5600 \mathrm{~km}^{2}$. In Nusa Tenggara Barat province, $57 \%$ of households have been classified as poor with the majority of the poor living in rural areas. In Lombok there are from 895,300 to 925,000 people classified as poor [7,8]. Table 1 provides select village data for Central Lombok that were used for this study.

Islam and its impacts on agriculture are not well studied. Water is valued spiritually by all religions including the roughly 2.6 million Muslims and 115,000 Balinese Hindus on Lombok. Muslim water law in Indonesia, establishes a fundamental duty to preserve and share water based on a priority of need [9]. Specifically, water is prioritized according to Islamic law as follows: right of thirst, domestic use including water for animals, irrigation, and lastly commercial and industrial uses [10]. Waste of water is forbidden in Islamic edicts and as a social justice concern, water equity is fundamental, always shared, and never horded. Further, water is a "gift from God" and can never be owned although ownership of water holding structures is possible.

Lombok has a strong tradition of dry land and wetland agriculture. Farm size averages about 0.47 ha. per household [11]. Rainfed agriculture involves capturing rainfall in catchment reservoirs (embung) and transferring water to fields or with rainfall caught directly in bunds. The gogorancah is a rice cultivation system for dry land ag- 


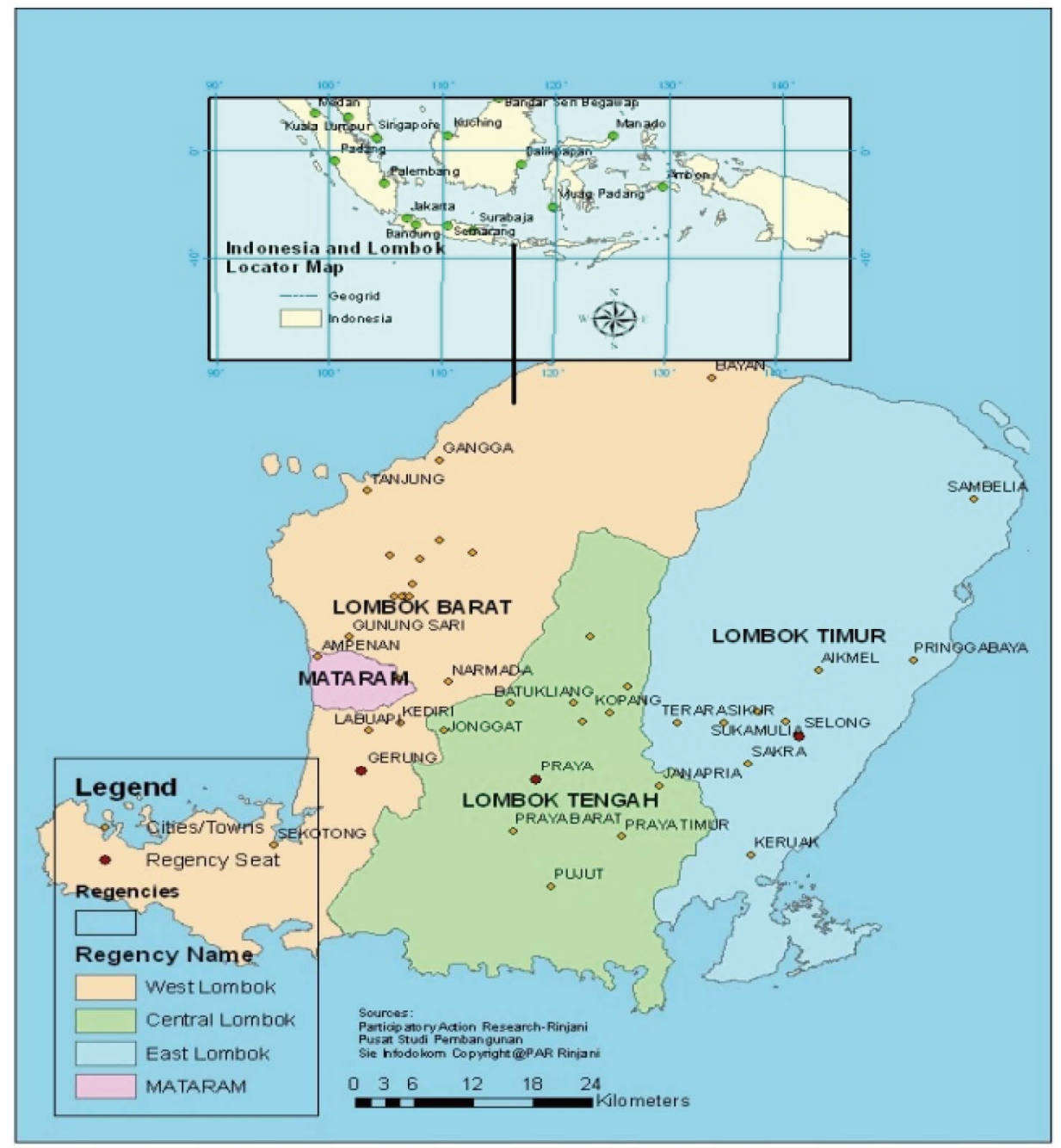

Figure 1. Map of Indonesia and Lombok.

riculture. In this system, rice is dry seeded in non-puddled fields. Introduced in 1980, this technology is more prominent in Central and Southern Lombok, as it is suit-able to drier conditions. Dry seeding takes place after two or three rainfall events. Following rice harvests of either one or two croppings, secondary crops (palawija) are planted including maize, cassava, capsicum peppers, soybeans, peanuts, sweet potato, mung beans, and tobacco. Farmers on Lombok produce high quality Virgina tobacco that is sold to the large cigarette companies operating in Indonesia [1].

Like the rest of the country, Lombok utilizes about $80 \%$ of its water for crops [12]. Rice production in Nusa Tenggara Barat has increased in both area and yield over the past 50 years. Similarly, the population in the province has also increased. These two factors, rice area increase, and human population increase, are major contributors to the current water stresses that are found in
Nusa Tenggara Barat.

\section{Conceptualizing Coping}

Agricultural coping strategies are diverse and involve calculations related to risk, management, and livelihood. Coping as proposed by Endler and Parker has three widely recognized dimensions: problem-focused coping; emotion-focused; and avoidance coping [13]. For our study, the authors use the terms "farmer adaptations" and "agricultural coping strategies" interchangeably and broadly. Both are defined here as meaning: "to contend with, or adjust to" a water shortage situation. Hence, for the purpose of this study, a coping strategy could involve problem-solving (technical, cropping, water allocation, payments, others) emotion-focused (discussions, sympathy, understanding with village heads, water-user and other groups and institutions) and avoidance (confrontation avoidance, saving face, religion). Resilience theory 


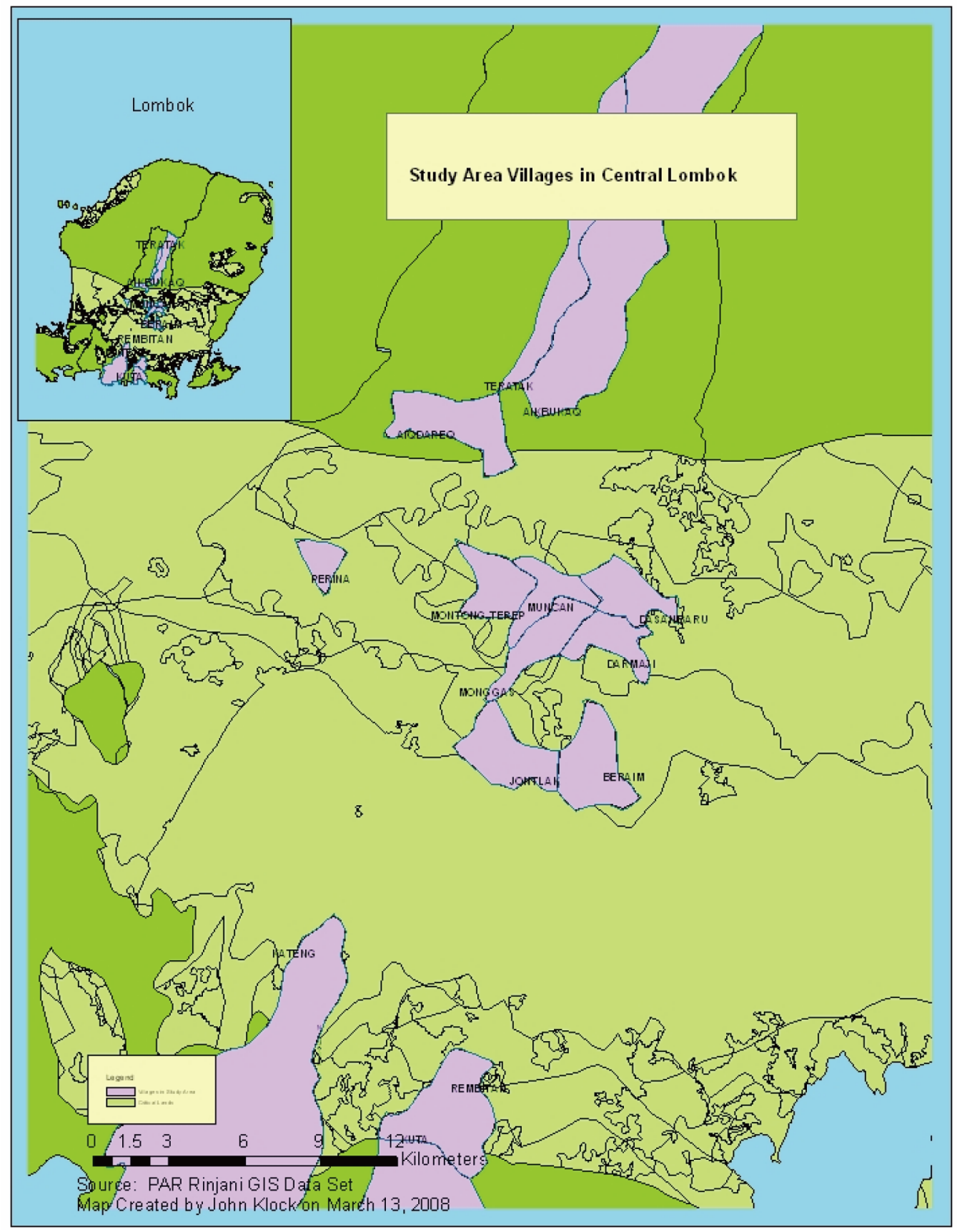

Figure 2. Map of Lombok and study area.

invokes a view of multiple states of a system; some goal of a desirable state; and the thresholds or boundaries of a system state. Related to this concept is adaptability which is the capacity of actors to impact the resilience of the system. The resilience of a community institution, like a water user association, is linked to such variables like water governance changes, access, population increase, urbanization, watershed damage, and climate change. Adaptation in relationship to resilience is the maintenance of a responsive capacity. As an example, a drought in Kenya might require a transformative action by farmers of selling assets while sources of resilience might include social networks and remittances [14].

The village heads interviewed suggested many means to addressing agricultural water shortages. Village leaders were interviewed because they can provide fairly concise explanations of local water issues, are often farmers themselves, and as leaders are under pressure to 
Table 1. Select village characteristics.

\begin{tabular}{|c|c|c|c|c|c|c|c|}
\hline Village Name & Population & $\begin{array}{c}\text { Elevation } \\
\text { (meters) }\end{array}$ & $\begin{array}{l}\text { Rainfall in } \\
\mathrm{mm} .\end{array}$ & $\begin{array}{l}\text { Village } \\
\text { Area } \\
\text { (has.) }\end{array}$ & $\begin{array}{l}\text { Primary } \\
\text { water } \\
\text { source }\end{array}$ & $\begin{array}{c}\text { Secondary } \\
\text { Water } \\
\text { Source }\end{array}$ & $\begin{array}{c}\text { Mosque } \\
\text { Hall \# }\end{array}$ \\
\hline 1. Pengembur & 11231 & $0-100$ & 1000 & 47870 & well & well & 41 \\
\hline 2. Kateng & 10699 & $0-100$ & 1000 & 2234 & well & river/lake & 41 \\
\hline 3. Dasan Baru & 7951 & $0-100$ & 1000 & 5340 & well & well & 20 \\
\hline 4. Rembitan & 4983 & $0-100$ & 1000 & 14750 & well & well & 34 \\
\hline 5. Kuta & 5649 & $0-100$ & 1000 & 12700 & well & well & 12 \\
\hline 6. Dharmaji & 6402 & $101-250$ & $1000-1500$ & 4400 & well & well & 2 \\
\hline $\begin{array}{l}\text { 7. Montong } \\
\text { Terep }\end{array}$ & 9056 & $101-250$ & $1000-1500$ & 4880 & well & river/lake & 52 \\
\hline 8. Muncan & 8373 & $101-250$ & $1000-1500$ & 4700 & well & well & 29 \\
\hline 9. Jontlak & 5962 & $101-250$ & $1000-1500$ & 7760 & well & well & 47 \\
\hline 10. Beraim & 5366 & $101-250$ & $1000-1500$ & 8390 & well & well & 35 \\
\hline 11. Perina & 2595 & $101-250$ & $1000-1500$ & 2887 & well & well & 10 \\
\hline 12. Teratak & 11834 & $>251$ & $>1500$ & 13062 & spring & spring & 43 \\
\hline 13. Aik Bukaq & 11531 & $>251$ & $>1500$ & 12774 & spring & spring & 45 \\
\hline 14. Aik Beriq & 14889 & $>251$ & $>1500$ & 14832 & spring & spring & 58 \\
\hline
\end{tabular}

secure resources (information, charity, extension, or government involvement) for constituent farmers.

Sustainability implies keeping harvest rates of renewables equal to regeneration rates. The sustainable use of water during seasonal shortages and drought is critical for family survival and may involve several measures such as: farmer preparedness; changes in water allocation and delivery; farmer adaptation and coping to reduced demand; and income support [15]. In over 400 villages in Northern China, farmers adopted water saving technology as a result of severe water shortages from dropping water tables and chronic drought [16]. Blanke and colleagues documented three groups of technical water saving strategies: traditional (border and furrow irrigation techniques); household (drought resistant varieties, plastic sheeting, and low till-stubble plowing, and village-based (canal lining and underground piping).

Farmer coping strategies take on several forms and involve diverse aspects of farmer behavior, risk management, and livelihood selection. Ding constructs two types of rice farmer coping strategies, ex ante and ex post [17]. Ex ante coping involves risk reduction prior to the production shortfall including spatial diversification of farms, diversification of agricultural enterprises, and changes from farm to off-farm activities. Ex post are coping strategies included migration, loans, asset liquiddation, and reliance on charity. Internationally, in many developing countries, the infrastructure for measured and restrained water delivery is not available [18]. In cases where water infrastructure is present, it is often managed from the top-down and gives farmers little flexibility and few options for coping with water shortages [19].

Psychological coping is defined as a conscious response to external stressful or negative situations [13]. Many interdisciplinary studies on environmental degradation now take behavior into account. As Haaften et al. point out, farmers who experience high levels of psychological distress are unlikely to show behaviors that halt environmental degradation [20]. Psychological resilience is influenced by stress, depression, and marginalization [20]. Conversely, successful natural resource management addresses the psychological stressors affecting humans in order to achieve cooperation on environmental restoration.

\section{Factors Contributing to Water Shortages}

\subsection{Water User Associations}

How farmers organize themselves to manage water and how the government manages water user associations (WUAs) ultimately have big impacts on whether farmers 
have the flexibility to deal with periods of drought. It is important to analyze water governance and allocation in the context of farmer coping mechanisms. Many researchers have examined WUAs in Indonesia and their impacts on farmers, community structure, and poverty [21-23].

Since the 1980s, the government has made irrigation development a priority in order to achieve self-sufficiency in rice [22]. The government strategy in irrigation was multi-faceted including: targets for physical development; engineering-based design and management; uniform models and functionality across the country; and a centrist approach guided by the national government. Through these efforts there were four million ha. of irrigated rice by 1990 [22]. While the country achieved rice self-sufficiency, these measures did not necessarily improve the welfare of farmers. The priority of the government is now to strengthen the capability of WUAs and WUA federations so that they can play an effective role in water governance, water distribution and assume complete responsibility for tertiary projects in both operation and maintenance [24].

Starting in 1984, the government of Indonesia wisely recognized that small-scale irrigation systems (less than 500 ha. needed to be turned over to WUAs in order to provide for operation and maintenance. As a whole, irrigation maintenance has been continuously deferred due to budget constraints. Currently, the World Water Council [12] reports that about $50 \%$ of irrigation schemes require heavy maintenance and rehabilitation in Indonesia. At this time massive investment is needed in irrigation infrastructure across the country but only Rp. 350 billion (US \$ 40 million) is allocated annually for operation and maintenance of public irrigation schemes by the Indonesian government. In budgetary terms, only $15 \%$ to $40 \%$ of the operation and maintenance funds for irrigation, given as a block grant to the provinces, are actually used for repairs. Local and provincial corruption, approaching $30 \%$, must also be factored.

Roth [21] noted that farmers are somewhat passive about irrigation in Ketoraharjo, Sulawesi, Indonesia. As one government official noted there, farmers have been "pampered" by the government. They have been the beneficiaries of land, irrigation systems, and abundant WUA trainings. Still farmers do not attend WUA meetings or perform collective labor. Lack of participation could relate to the top-down irrigation development that the government has promoted for decades. Roth further notes that many tertiary units have serious maintenance problems in Ketorahnarjo.

\subsection{Lombok WUAs}

The farmers of Lombok manage their irrigation water management through the PPPA (Perhimpunan Petani Pemakai Air) WUAs. The PPPA are an offshoot of a 1990s government policy to turnover irrigation infrastructure to local communities via the WUAs. The PPPA are a relatively new but cooperative irrigation management in the form of subak that has been present in Lombok for some time. These traditional management structures were subverted across Indonesia starting in 1965, by the Suharto regime's implementation of uniform organizational codes. The WUA and PPPA have replaced the traditional subak [8]. Seventeen of the nineteen villages surveyed in this study had PPPA organizations. The two villages without a PPPA organization did not have enough water to manage via the PPPA.

The Lombok irrigation culture was adopted from the Balinese subak system via Balinese control and conquest [25]. Many farmers describe their water user group as a subak in Lombok, but in practice, the subak in Lombok are in name only and have little of the accouterments or elements found in Bali (Sayuti 2004). Human organization of subaks in Bali, is due partly to the need for human manpower to address the shortage of water, coordinate pest removal in fields, and to prevent flooding [26]. The farmers in Bali are organized into irrigation societies, in which each society has a religious head and is composed of 50 to 400 farmers, groups called subak [26-28]. Schoenfelder describes a scenario in which the Balinese began to organize themselves when the density of rice terraces became too great [26].

\subsection{Payments for Water}

Water user association payments are important for longterm sustainability of WUAs but are problematic for poor farmers. Agricultural water studies indicate that the price paid for irrigation water in Lombok has been undervalued [29]. Our interviews completed in central Lombok confirm that the payment system for water was mostly based on in-kind payments called suwinih. Suwinih payments from farmer to pekasih (canal manager) for water varied but ranged from 10,000 - 30,000 rupiah (US \$1.00 - US \$3.00) per ha for rice and 300,000 rupiah (US \$35.00) per ha for tobacco. Payments for water took place every cropping season or on a voluntary basis. The WWF study noted that the irrigation fee requested of farmers has been too low and not sufficient to pay the operation and maintenance costs of the irrigation scheme [29]. Rather the cost paid is mostly payment to the irrigation officers.

Local governments initially introduced IPAIR fees of Rp 15,000 to 30,000 per year but most fees could not be collected successfully. The ADB operations and evaluation visit to Lombok in December of 1999 confirmed that only 1 of the 13 schemes visited were collecting fees in 
Lombok and elsewhere in West Nusa Tenggara [24]. The $\mathrm{ADB}$ estimated that at least $\mathrm{Rp} 425,000$ ( $\$ 50$ equivalent)/ha. was needed per farmer per year for sustainable operation and maintenance or irrigation structures operated by WUAs.

\subsection{Village Level Concerns in Central Lombok}

Among the many concerns expressed by kepala desa in Central Lombok were the bribes or incentives needed to obtain or maintain water supplies. Such rent-seeking behavior was noted to take place between farmers and pekasih, farmers and juru pintu air or juru air (water gate manager and government employee under agency Kimprasswill) and farmers and embung operators. Payments were more common during the critical second cropping season when demand for water was highest. Payments were also required to prevent theft of water, such as one village where people were paid to watch key irrigation canal junctions. It should be noted that illegal or unnecessary payments for water were mentioned in interviews in five of the nineteen villages surveyed.

Water storage facilities, particularly small village reservoirs (embung) were noted to be in high demand. In Java, reservoirs are shown to have a very good return on investment [30]. Reservoir presence in rain-fed Southern Lombok was seen as critical to farmer survival. Two villages noted flooding as a problem during the rainy season and one, notably Tumpak village was lacking both reservoir storage capacity and also enduring seasonal flooding.

In three villages, there was uneasiness over the appropriation of springs by the water utilities (PDAM) without adequate compensation, notably Aik Bukaq, and Air Berik.

Villagers expressed concern at the high price of gasoline (benzene) for pumping. Ranging from 20,000 to 30,000 rupiah ( $\$ 2.50$ to $\$ 3.50$ ) per hour, farmers pumped water from wells to fields via sumer bor (bore-hole wells). Extension services appeared weak in the study areas, especially for water-saving technologies like drip irrigaton. Getting enough water therefore seemed to be the sum of a combination of factors, but a big factor noted in most village interviews was the need for good relations among the stakeholders.

\subsection{Watershed Degradation}

Degraded watersheds have resulted in unstable river flows. In Indonesia, there are 59 degraded river catchments [12]. In Lombok, the Mount Rinjani catchment is more accessible and perhaps in better condition than others, but during the last twenty years, more than 400 springs have dried up on Mount Rinjani most likely from deforestation [31].

\section{Results and Discussion}

The elevation and precipitation were confounded with each other and as a result it was not possible to separate the influences of rainfall or elevation on the coping scores.

Using backward elimination in this model, the mosque number and presence of wells turned out to be the most significant (Table 2). Mosque hall number and well water source were the most significant independent variables for this study. For each additional mosque, the weighted score, for example would increase by 0.0457 . Well water as a primary source in a village versus a town that did not have well water, showed a weighted score of 2.26. R-squared was calculated to determine model fit and in this analysis, the model explained 60 percent of the variability in the weighted score.

Presence of mosques and well water overall suggests that more coping strategies might be available to farmers during water shortages.

Mosque hall number and well water \#1 were left in the model as significant and from the weighted score, the data suggests that.

Under the sub-category of village water institutions, of which there were four coping strategies, mosque number was again significant.

\subsection{Common Strategies Observed for Water}

There were several common water management strategies that emerged from interviews. These included: methods of organization, cropping systems, water allocation mechanisms, methods of compromise, payments, and traditional water management practices (please see Table 3).

The methods of organization found in villages included relationships between pekasih and farmer, pekasih and juru air, PPPA and pekasih, PPPA and farmer. The PPPA is really the body of compromise and negotiation and its presence is necessary in the creation of the

Table 2.

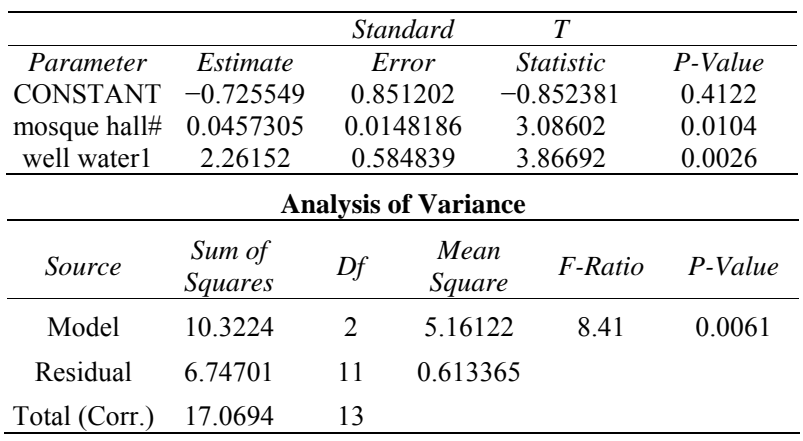

R-squared $=60.4732 \%$

R-squared (adjusted for d.f.) $=53.2865 \%$ 
Table 3. Farmer coping categories and strategies in central Lombok.

\begin{tabular}{|c|c|c|}
\hline Categories & Strategies & Characteristics \\
\hline $\begin{array}{l}\text { Village Institu- } \\
\text { tions }\end{array}$ & $\begin{array}{l}\text { +PPPA } \\
\text { +Baden musyawarah } \\
+ \text { Pekaseh } \\
\text { +Village head and coun- } \\
\text { cil }\end{array}$ & $\begin{array}{l}\text { +Functional water me- } \\
\text { diation body } \\
+ \text { Compromise empha- } \\
\text { sized } \\
+ \text { Community support } \\
\text { body } \\
\text { +can implement fines, } \\
\text { effect ostracization } \\
+ \text { farmers may negotiate } \\
\text { water themselves by- } \\
\text { passing PPPA }\end{array}$ \\
\hline $\begin{array}{l}\text { Spiritual/Social } \\
\text { Justice/Good } \\
\text { Neighbor Prac- } \\
\text { tices }\end{array}$ & $\begin{array}{l}\text { +Village has water prior- } \\
\text { ity based on religious/ } \\
\text { social grounds } \\
\text { +Cultural politeness/ } \\
\text { avoids embarrassment } \\
\text { and a priority on getting } \\
\text { along } \\
\text { +Equality (everybody } \\
\text { gets equal amounts of } \\
\text { water even it it is little or } \\
\text { none) }\end{array}$ & $\begin{array}{l}\text { "It is up to God; God } \\
\text { will provide" } \\
\text { "Water is given by god" }\end{array}$ \\
\hline $\begin{array}{l}\text { Cropping sys- } \\
\text { tems/Traditiona } \\
1 \text { Practices }\end{array}$ & $\begin{array}{l}\text { +Awig-awig } \\
\text { +Gotong-royong } \\
\text { +Subak } \\
\text { +Villages use two or } \\
\text { more cropping systems } \\
\text { per year }\end{array}$ & $\begin{array}{l}\text { +Flexibility in farmer } \\
\text { cropping choices during } \\
\text { drought } \\
\text { + traditional law } \\
\text { + traditional labor mobi- } \\
\text { lization } \\
\text { +remnants of Hindu } \\
\text { irrigation structure }\end{array}$ \\
\hline $\begin{array}{l}\text { Payments/Fines } \\
\text { for Water }\end{array}$ & $\begin{array}{l}\text { +Suwinih } \\
+ \text { bribes or individual } \\
\text { payments } \\
+ \text { IPAIR (formal water } \\
\text { fees) } \\
+ \text { Fine for Theft }\end{array}$ & $\begin{array}{l}\text { +flexible in-kind pay- } \\
\text { ments, often based on } \\
\text { crop type but can } \\
\text { change if crop failure } \\
\text { occurs }\end{array}$ \\
\hline $\begin{array}{l}\text { Actions against } \\
\text { illegal use }\end{array}$ & $\begin{array}{l}\text { +Ostracization } \\
+ \text { Police } \\
+ \text { Allocation by height in } \\
\text { paddy }\end{array}$ & \\
\hline $\begin{array}{l}\text { Allocation } \\
\text { Methods }\end{array}$ & $\begin{array}{l}\text { +alternating by rotation } \\
\text { (East to West and vice- } \\
\text { versa) } \\
\text { +Alternating by time } \\
\text { +Just enough for phy- } \\
\text { siological growth }\end{array}$ & $\begin{array}{l}\text { +Allocation by means } \\
\text { of volume, time, rota- } \\
\text { tion, and plant physiol- } \\
\text { ogy }\end{array}$ \\
\hline $\begin{array}{l}\text { Water Stor- } \\
\text { age/Acquisition } \\
\text { Methods }\end{array}$ & $\begin{array}{l}\text { +Embung-micro water } \\
\text { catchments } \\
\text { +Pumps water from } \\
\text { wells into fields } \\
\text { +Irrigation water from } \\
\text { springs } \\
\text { +Irrigation water from } \\
\text { dams/reservoirs }\end{array}$ & $\begin{array}{l}+ \text { Critical as rain-fed } \\
\text { irrigation source }\end{array}$ \\
\hline $\begin{array}{l}\text { Protest/Petion } \\
\text { for Ser- } \\
\text { vices/Other }\end{array}$ & $\begin{array}{l}\text { +Village residents pro- } \\
\text { test water shortages to } \\
\text { the government } \\
\text { +Letters to government } \\
\text { +Migration }\end{array}$ & \\
\hline
\end{tabular}

water schedule in coordination with the pekasih. The WUA or PPPA is supposed to represent the best interests of the farmer and farmers in turn must trust the organiza- tion in getting the best deal and accept the results. In some cases, villages with several PPPA can form a union and organize for better negotiation and delivery of water with the Juru Air. The subak in Lombok are defined differently than those in Bali. In Lombok, the subak is equivalent to a farmer or a land area controlled by farmers but has lost most of the sophistication and trappings of subak societies found in Bali. The PPPA water user associations pushed by the government appear to have displaced the subak.

\subsection{Allocation Methods}

The were varied water allocation mechanisms found among villages in central Lombok including: allocation by height of water in paddock (anywhere from 5 to 10 $\mathrm{cm}$ ); by giving just enough water to ensure rice or palawija growth; by rotation: alternating from east to west, or left to right; allocation by time such as two nights and two days per every 5 ha.; and allocation by cropping season: $1^{\text {st }}$ season everyone gets abundant water; $2^{\text {nd }}$ season water is allocated by time; $3^{\text {rd }}$ season allocated by "just wet enough" saturated soil to allow plant growth. In some water plentiful sites, farmers were known to negotiate amongst themselves and bypass the PPPA altogether.

\subsection{Cropping Systems}

Cropping systems noted in this study were adapted to irrigation and irregular rainfall. Some of the patterns noted here were: Padi-padi-palawija (rice-rice-non-rice dryland crop); padi-palawija; padi-padi-padi; padi-tobacco and others. The flexibility of the cropping system is essential for farmer survival. Dryland areas rarely had more than one rice crop per year unless they had access to a water source. Tobacco is a much planted cash crop that commands a high price but requires high irrigation water payments.

\subsection{Social Coping Mechanisms}

The art of compromise is considered an important theme for water management in central Lombok. The baden musyawarah is a type of community deliberation that can be used to solve water disputes and form a compromise with PPPA, Pekasih or even Juru Air especially in the cases of the water schedule and method of allocation. The payment system for water is based on in-kind payments called suwinih. Suwinih payments from farmer to pekasih for water varied but ranged from 10,000 - 30,000 rupiah $(\$ 1.00$ - \$3.00) per ha for rice and 300,000 rupiah $(\$ 35.00)$ per ha for tobacco. Payments for water took place every cropping season. As mentioned earlier, incentives (extra payments) were needed to get extra or needed water as well as to maintain amicable and healthy 
relationships between the parties.

\subsection{Impact of Traditions and Beliefs}

Several traditional water management practices are noted here. Some villages have implemented awig-awig (traditional rule) for agricultural water use and penalties for theft. The gotong royong (community help culture) was still strong in all villages, and used for rice harvests, planting and to keep irrigation facilities repaired. Islam plays a dominant role in water shortage problem solving. Muslim law prioritizes water for drinking and bathing (purifying before prayer) first followed by animals, and irrigation. Islam can serve as a spiritual coping strategy to water stress.

\section{Mosque and Hajj Numbers}

From Table 4 the number of mosques in Lombok for 2005 was 2522. In 1974, the estimate was 1437 and for the year 1930. Two methods were used to determine mosque number. 1:25,000 scale topographic maps from the Dutch colonial period were analyzed for the time period from 1926 to 1931 (Government 1926-1931). From these maps, 171 mosques were counted for West, Central, and East Lombok. The mosque numbers reveal an increase from 1900 to 2200 mosques over a 75 year period from 1930 to 2005 . The mosque growth rate on Lombok plays a role in landscape modification. Mosque placement and construction are related to the population that can support the institution. Water is needed at the entrance of a mosque for bathing to ensure ritual purity. In Lombok, this source can come from a well, spring, or piped water. The challenge in this research has been to obtain a reasonably accurate figure for mosques for the years 1930, 1975 and 2005. Tables 4 and 5 provide some approximate mosque and hajji numbers and estimates for the years 1930, 1975, and 2005. From Table 5, as the number of hajji (Mecca pilgrims) have increased; they may have an influence on the rise in mosque numbers, but this relation was unclear.

The authors noted a strong moral component found in

Table 4. Mosque count.

\begin{tabular}{cccc}
\hline Year & Mosque Count & Source & Method \\
\hline 1930 & Est. 171*, and & [33] & Hand count, ex- \\
& $574^{* *}$ & & trapolation \\
$1974-1975$ & Est. 1437*** & & Extrapolation \\
2005 & 2522 & {$[3]$} & Govt. statistics \\
\hline
\end{tabular}

Table 5. Haji count.

\begin{tabular}{cccc}
\hline Year & Pilgrim Count & Source & Method \\
\hline 1930 & 426 & $* * * *$ & Extrapolation \\
$1974-1975$ & $\begin{array}{c}1040 \text { (prov- } \\
\text { ince-wide) } \\
2072\end{array}$ & {$[32]$} & \\
2005 & {$[3]$} & Govt. statistics \\
\hline
\end{tabular}

village authority often involving religious organizations that helped to maintain peace in the village. Islamic law and local institutions can mete out fines for stealing water, or in some rare cases, ostracizing individuals. Some villages were noted to utilize what might be called an "equitable suffering scenario" whereby all people in the village would get by equally with little water in any one season. In another scenario, most people would suffer during the dry season but a few farmers have the ability to pay for water. Other short-term or irregular mechanisms included protest and petitioning to the water utilities over questionable appropriation of springs.

\subsection{Cooperation among Villages}

From village interviews, two generalizations were used to characterize villages. First, villages situated north of the town of Praya and at higher elevations, had on the whole, more water supplies than villages south of Praya. Secondly, villages in wetter areas had greater inter-village cooperation while villages in drier areas had greater intra-village cooperation. The reasons for these conditions were not clear, but it appeared that drier villages in Southern Lombok were more autonomous and self-sufficient possibly due to seasonally lower rainfalls, lack of springs or access to other water supplies. Southern Lombok villages did not have strong links with other villages, presumably because there was not abundant water to share. Water abundant villages had stronger cooperative networks between neighboring villages because PPPA, pekasih, and farmers in different villages had to coordinate water flow between villages.

Water management at the village level varies according to climate and type of agriculture supported, the number of village reservoirs, whether villages are lucky enough to get irrigation infrastructure from government funding, and whether villages are fortunate enough to be near a major dam (i.e. Batu Jai in central Lombok), river or spring. Impounded water is used in Indonesia commonly for supplemental irrigation of the first rice crop during the rainy season, and thereafter for watering the second crop in the dry season [30]. Reservoirs are filled by direct rainfall which often constitutes about $1 / 3$ of inflows with another $2 / 3$ filling the reservoir from runoff.

\section{Conclusions}

This paper has presented several means by which villagers in central Lombok prepare themselves for dry season water stress. We hypothesized that Lombok farmers used unique strategies to deal with water shortages under high population densities. Coping involves wide latitude of strategies pursued by farmers. We noted that villages with more water supplies had greater inter-village cooperation, and were better organized to interact with neigh- 
boring villages. The reasons for this were unclear but villages in drier areas tended to be more autonomous, and have more cooperation within the village (intra) but having fewer water links to other villages Water abundance seemed to influence organization and cooperation more than anything else.

Indonesia has facilitated a heavy-handed top down construction and management of irrigation facilities and WUAs. Government and sectoral decentralization is taking place in Indonesia. It has and will take some time for water user associations to become more financially independent and autonomous. Future agricultural water shortages will require more efficient water user associations, currently called PPPA. The PPPA is really the body of compromise and negotiation. Maintenance of irrigation infrastructure by the PPPA or village will be essential and may have to be more and better conceived. The organizational relationships found in villages included: relationships between pekasih and farmer, pekasih and juru air, PPPA and pekasih, PPPA and farmer

The water allocation tactics found among villages in central Lombok were varied and included allocating water by time, location, height in paddock, and soil moisture content. Compromise among stakeholders is not an option but a necessity that involves a good deal of give and take to not only get, but also to maintain water supplies for one cropping season. The badan musyawarah is a type of community deliberation that can be used in solving water disputes and other civic problems.

Cropping systems in central Lombok were flexible and adaptable to the shifts in irregular rainfall. The payment system for water is based on in-kind payments called suwinih. Incentives (extra payments) were identified as a means to get extra or needed water as well as to maintain amicable and healthy relationships between the parties.

Some strong traditional water management practices found in central Lombok were the awig-awig, and the gotong royong (community help culture). The subak has been largely displaced by the government sponsored WUAs over the last three decades.

The inability of the government to allow for bottom-up management and flexibility in water delivery has put pressure on farmers to utilize their own unique water management and coping skills in times of water shortages. These coping innovations by farmers and villages could be considered sustainable practices in that they allow farmers to solve immediate water problems. This research provides a starting point for the study of adaptive capacities under a resilience framework when placed within the broader social and ecological systems in Lombok.

\section{REFERENCES}

[1] K. Monk and Y. De Fretes, "The Ecology of Nusa Tenggara and Maluku," Periplus Editions, Hong Kong, 1997.

[2] I. Yasin, M. Ma'shum, H. Idris and Y. Abawi, "The Impact of Inter-annual Climate Variability on Water Resource and Crop Production in Lombok," University of Mataram Press, Mataram, 2007.

[3] Badan Pusat Statistic, "Statistic Potensi Desa Provinsi," Nusa Tenggara Barat, Mataram, 2005.

[4] W. Prayitno, "PAR Rinjani: Data Lahan Kritis dan Mata Air di Pulau Lombok," 2005.

[5] P. Gelles, "Competing Cultural Logics: State and Indigenous Models in Conflict," In: R. G. D. Boelens, Ed., Searching for Equity, Conceptions of Justice and Equity in Peasant Irrigation, Van Gorcum Ltd., 1998.

[6] M. Mahrup, A. Borrel, M. Ma'shum , I. G. M. Kusnarta, Sukartono, J. Tisdall and J. Gill, "Soil Management Systems Improve Water Use Efficiency of Rainfed Rice in the Semi-Arid Tropics of Southern Lombok, Eastern Indonesia," Asian Crop Science Conference, Brisbane, 2005, pp. 342-344.

[7] H. Mitsuda, R. Sayuti, et al., "Sustainable Lombok: The Rich Nature and Rich People in the 21st Century," Universitas Mataram Press, Mataram, 2005.

[8] S. Suryadi, "Community Forestry Institutionalized: Never or Ever: The Community Forestry Program at Sesaot Village in Nusa Tenggara Barat Province of Indonesia," East-West Center, Honolulu, 2004.

[9] S. Sarwan, T. Subijanto and C. Rodgers, "Development of Water Rights for Indonesia,” International Food Policy Research Institute, Washington, 2003.

[10] N. I. Faruqui, A. K. Biswas and M. J. Bino, "Water Management in Islam,” I.D.R. Center, Tokyo, 2001.

[11] I. Patrick, "Contract Farming in Indonesia: Smallholders and Agribusiness Working Together," Australian Centre for International Agricultural Research, Canberra, 2004.

[12] World Water Council, "Water Resources Management towards Enhancement of Effective Water Governance in Indonesia," The 3rd World Water Forum, Tokyo, March 2004.

[13] N. S. Endler and J. D. A. parker, "Assessment of Multidimensional Coping: Task, Emotion, and Avoidance Strategies," Psychological Assessment, Vol. 6, No. 1, 1994, pp. 50-60. doi:10.1037/1040-3590.6.1.50

[14] D. R. Nelson, W. N. Adger and K. Brown, "Adaptation to Environmental Change: Contributions of a Resilience Framework," Annual Review of Environment and Resources, Vol. 32, 2007, pp. 395-419. doi:10.1146/annurev.energy.32.051807.090348

[15] L. Pereira, T. Oweis and A. Zairi, "Irrigation Management under Water Scarcity," Journal of Agricultural Water Management, Vol. 57, No. 3, 2002, pp. 175-206. doi:10.1016/S0378-3774(02)00075-6

[16] A. Blanke, S. Rozelle, B. Lohmar, J. Wang and J. K. Huang, "Water Saving Technology and Saving Water in 
China," Agricultural Water Management, Vol. 87, No .2, 2007, pp.139-150. doi:10.1016/j.agwat.2006.06.025

[17] S. Ding, S. Pandey, C. Chen and H. Bhndari, "Drought and Farmers' Coping Strategies in Poverty-Afflicted Rural China," University of Manchester, 2005.

[18] M. Qadir, Th. M. Boers, S. Schubert, A. Ghafoor and G. Murtaza, "Agricultural Water Management in Water-Starved Countries: Challenges and Opportunities," Agricultural Water Management, Vol. 62, No. 3, 2003, pp. 165-185.doi:10.1016/S0378-3774(03)00146-X

[19] D. Molden, “Water for Food, Water for Life: A Comprehensive Assessment of Water Management in Agriculture," Earthscan and International Water Management Institute, London and Columbo, 2007.

[20] E. H. van Haaften, Z. R. Yu and F. R. Van de Vijver, "Human Resilience in a Degrading Environment: A Case Study in China," Asian Journal of Social Psychology, Vol. 7, No. 2, 2004, pp. 205-219. doi:10.1111/j.1467-839x.2004.00142.x

[21] D. Roth, "Which Order? Whose Order? Balinese Irrigation Management in Sulawesi, Indonesia," Oxford Development Studies, Vol. 34, No. 1, 2006, pp. 31-46. doi:10.1080/13600810500495956

[22] I. Hussain, "Pro-poor Intervention Strategies in Irrigated Agriculture in Asia: Poverty in irrigated agriculture: Issues and options. Country Report, Indonesia," International Water Management Institute, Columbo, 2004.

[23] Helmi, "Transition of Irrigation System Management in Indonesia: Challenges and Opportunities for Sustainability," Conference on the International Association for the Study of Common Property Resources, ed. I. University, Bloomington, 2000.
[24] ADB, "Performance Evaluation Report: Indonesia: Capacity Building Project in the Water Resources Sector," Jakarta Asian Development Bank. December 1999, "Project Performance Audit Report on the Nusa Tenggara Agricultural Development Project," Asian Development Bank, Jakarta, 2006.

[25] M. P. M. Judd, "Social Impact Study: Lombok Island Water Resources Development," Crippen International Vol. 2, Vancouver, 1978.

[26] J. Schoenfelder, "The Co-Evolution of Agricultural and Sociopolitical Systems in Bali," Bulletin of the Indo-Pacific Prehistory Association, Vol. 20, 2001.

[27] C. Geertz, "Organization of the Balinese subak," Cornell University Press, Ithaca and London, 1980.

[28] J. S. Lansing, "Priests and Programmers: Technologies of Power in the Engineered Landscape of Bali," Princeton University Press, Princeton, 2007.

[29] World Wildlife Fund Nusa Tenggara Program, "Payment for Environmental Services: Lombok Case," WWF, Nusa Tenggara Program, Mataram, 2006.

[30] P. Perez, "On-farm Reservoirs for Supplemental Irrigation. From Slash and Burn to Replanting," World Bank, Washington, 2004.

[31] LombokPost, "Springs Drying up on Gunung Rinjani," November 27, 2005.

[32] R. Daroesman, "An Economic Survey of West Nusa Tenggara," Bulletin of Indonesian Economic Studies, Vol. 12, No. 1, 1976, pp. 44-69. doi:10.1080/00074917612331332829

[33] Royal Tropical Institute, "1:25:000 Topographic Map Series of Lombok Mataram and Cakranegara and South," Batavia, Jakarta, 1926-1931. 